\title{
Child Neurology: An infant with episodic facial flushing
}

\section{A rare case and review of congenital harlequin syndrome}

Jennifer H. Kang, MD, * Muhammad Shahzad Zafar, MBBS, * and Klaus-Georg E. Werner, MD, PhD

Neurology ${ }^{\circledR}$ 2018;91:278-281. doi:10.1212/WNL.0000000000005949

\author{
Correspondence \\ Dr. Kang \\ Jennifer.kang@duke.edu
}

\begin{abstract}
Congenital harlequin syndrome is rare dysautonomia of the face most often reported in adults and rarely in infants and children. It is a diagnosis of exclusion and a seemingly benign condition. We report a case of a 6-month-old girl with episodic unilateral and bilateral facial flushing provoked upon awakening and resolved with sleeping with associated autonomic features consistent with harlequin syndrome. This is followed by a review of cases identified regarding this condition in infants and children.
\end{abstract}

\section{Introduction}

A 6-month-old girl presented to the neurology clinic with episodes of hemifacial flushing since 5.5 weeks of age. These were associated with lacrimation, eyelid edema causing ptosis, and nasal congestion (figure 1). Although there had been a previous note of isolated anisocoria without other signs of Horner syndrome, the patient's pupils were $3 \mathrm{~mm}$, symmetric, and reactive when evaluated during and in between these episodes in the hospital. Ptosis was attributed to her eyelid swelling (figure 1A). Initially they occurred every 2 weeks and came and went episodically for 2 days at a time. The episode would appear about 10-20 minutes after awakening, lasted throughout wakefulness, and resolved with sleep, including naptimes. It would typically be unilateral and on the upper part of either side of the face, although at times it would be bilateral (figure 1). At first, she did not appear to have any signs of distress during the episodes. As they continued, she would sometimes have a breath-holding spell preceding an episode of flushing. However, during the episodes of flushing, the patient would otherwise seem unbothered. One time, the episode was associated with a fever $\left(101.3^{\circ} \mathrm{F}\right)$, but no other vital sign abnormality, and as the episode resolved, her fever resolved. She had unremarkable medical and birth histories and no developmental concerns. Her general and neurologic examination results were normal. Complete blood count and metabolic panel were unremarkable. Neither parent had relevant medical history. They could not identify a provoking factor, but noted that the patient's symptoms would only occur while she was awake.

The patient's workup was unremarkable, including normal prolonged video EEG to rule out autonomic seizure, MRI of brain, neck, and chest to rule out a compressive lesion or syrinx, and magnetic resonance angiography (MRA) of the head and neck to rule out a vascular lesion.

The patient was diagnosed with harlequin syndrome given negative workup and provocation during wakefulness with associated autonomic symptoms. She was managed conservatively with close follow-up since case reports report this being a benign condition, with patients 
having reduced number of episodes over time. Several months later, her episodes were reduced in frequency.

Consent for the publication of this case report was obtained from the parents of the child.

\section{Discussion}

Harlequin syndrome is a rare dysautonomia of primarily the face defined as paroxysmal hemifacial flushing and sweating, induced by exercise, stress, or heat, which does not affect the other side of the face. ${ }^{1,2}$ It is different from harlequin color change, which is simply a benign transient skin change seen mainly in the neonatal period. ${ }^{3}$ Harlequin syndrome that involves a transient skin change with autonomic features was first described in 1988 by Lance et al. ${ }^{1}$ It has been reported mainly in adults, but rarely in infants and children. ${ }^{2}$ It has been associated with Horner syndrome (ptosis, miosis, anhidrosis of the face) in half of cases (table), and is on a spectrum of autonomic disorders associated with parasympathetic and sympathetic dysfunction, including Holmes-Adie or Adie syndrome (tonic pupils, hyporeflexia) ${ }^{4}$ and Ross syndrome (a combination of harlequin, Adie syndrome, and more diffuse autonomic symptoms), which have only been reported twice in children. $^{5,6}$

From our research, only 10 cases of congenital harlequin syndrome with or without Horner syndrome have been identified (table). A PubMed search using the term "harlequin syndrome" produced 110 results, of which 10 cases of congenital harlequin syndrome were identified, 5 (50\%) of which were associated with congenital Horner syndrome. Upon review of the search results, 5 additional cases of patients with hemifacial flushing were discovered. Only one patient met clinical criteria for harlequin syndrome. All others had harlequin sign, isolated contralateral hemifacial flushing associated with congenital Horner syndrome or Ross syndrome. An additional PubMed search for the search terms "hemifacial flushing, congenital Horner's, harlequin phenomenon," did not yield any additional cases. The average age at diagnosis of all patients was 7 years (range 14 months-13 years), and average onset of symptoms 4.6 years (range 14 months-11 years). Patients with Horner syndrome had earlier onset of symptoms (average onset 2.2 years, range 18 months -3 years), compared to

Figure Photographs during episode
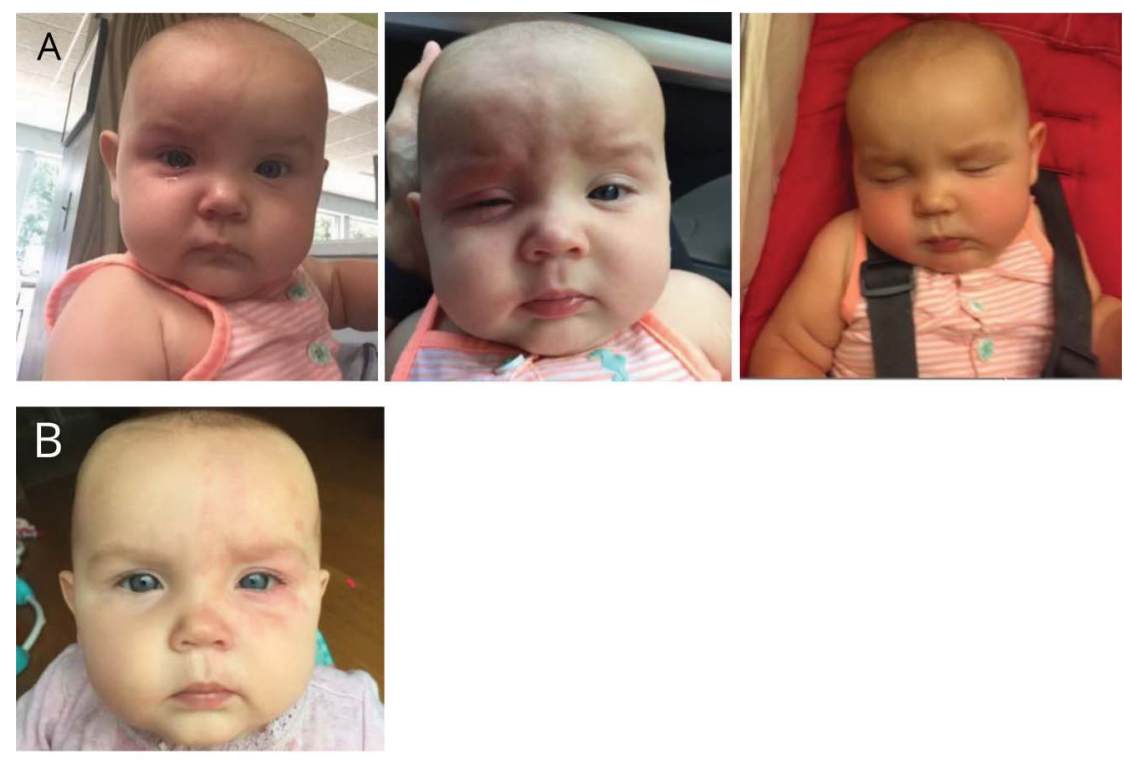

(A) July 25, 2017: right side of face, resolved when sleeping hours later. (B) September 6, 2017: left side of face. (C) September 7, 2017: bilateral eyes, resolved with sleeping. 
Table Congenital harlequin syndrome: Case reports in chronological order

\begin{tabular}{|c|c|c|c|c|c|c|}
\hline Authors & Age & $\begin{array}{l}\text { Age at onset } \\
\text { of symptoms }\end{array}$ & $\begin{array}{l}\text { Presenting } \\
\text { symptoms }\end{array}$ & Provoking factors & $\begin{array}{l}\text { Presence of } \\
\text { Horner } \\
\text { syndrome }\end{array}$ & $\begin{array}{l}\text { Presence of other } \\
\text { neurologic findings }\end{array}$ \\
\hline Saito $^{11}$ & $4 y$ & $3 y$ & $\begin{array}{l}\text { Right hemifacial } \\
\text { flushing and } \\
\text { hyperhidrosis }\end{array}$ & $\begin{array}{l}\text { Physical exercise } \\
\text { Bathing }\end{array}$ & $\begin{array}{l}\text { Yes, partial } \\
\text { because } \\
\text { equivocal or } \\
\text { absent ptosis } \\
\text { (contralateral } \\
\text { side) }\end{array}$ & No \\
\hline Jain et al. ${ }^{5}$ & $9 y$ & $6 y$ & $\begin{array}{l}\text { Anhidrosis of right } \\
\text { face, neck and left } \\
\text { arm, } \\
\text { trunk, leg with normal } \\
\text { to increased } \\
\text { hidrosis on } \\
\text { contralateral sides }\end{array}$ & NA & No & $\begin{array}{l}\text { Bilateral tonic pupils } \\
\text { Ocular } \\
\text { parasympathetic } \\
\text { denervation } \\
\text { supersensitivity }\end{array}$ \\
\hline Kaur et al. ${ }^{12}$ & $13 y$ & $11 \mathrm{y}$ & $\begin{array}{l}\text { Left hemifacial } \\
\text { flushing and } \\
\text { hyperhidrosis }\end{array}$ & $\begin{array}{l}\text { Prolonged physical } \\
\text { exercise } \\
\text { Emotional stress }\end{array}$ & No & No \\
\hline Kim et al. ${ }^{13}$ & $6 y$ & $4 y$ & $\begin{array}{l}\text { Left hemifacial } \\
\text { flushing and } \\
\text { hyperhidrosis }\end{array}$ & $\begin{array}{l}\text { Physical exercise } \\
\text { Heat }\end{array}$ & No & $\begin{array}{l}\text { Mild anisocoria } \\
(1.5 \mathrm{~mm} \text { OD, } 2.5 \mathrm{~mm} \\
\text { OS) }\end{array}$ \\
\hline $\begin{array}{l}\text { Vidal Esteban } \\
\text { et al. }{ }^{14}\end{array}$ & $14 \mathrm{mo}$ & $\begin{array}{l}\text { When he started } \\
\text { to walk } \\
\text { (unspecified) }\end{array}$ & $\begin{array}{l}\text { Left hemifacial } \\
\text { flushing and } \\
\text { hyperhidrosis }\end{array}$ & Physical exercise & No & Physiologic anisocoria \\
\hline Lucas et al. ${ }^{15}$ & $9 y$ & NA & $\begin{array}{l}\text { Right hemifacial } \\
\text { flushing and } \\
\text { hyperhidrosis }\end{array}$ & Effort & $\begin{array}{l}\text { Yes } \\
\text { (contralateral } \\
\text { side) }\end{array}$ & $\begin{array}{l}\text { Generalized } \\
\text { myoclonic epilepsy } \\
\text { Psychomotor delay } \\
\text { Mental retardation }\end{array}$ \\
\hline \multirow[t]{3}{*}{ Miquel et al. ${ }^{2}$} & $15 \mathrm{mo}$ & $\begin{array}{l}15 \text { mo (at onset of } \\
\text { walking) }\end{array}$ & $\begin{array}{l}\text { Left hemifacial } \\
\text { flushing and } \\
\text { hyperhidrosis }\end{array}$ & $\begin{array}{l}\text { Exertion } \\
\text { Hot weather }\end{array}$ & $\begin{array}{l}\text { Yes } \\
\text { (contralateral } \\
\text { side) }\end{array}$ & No \\
\hline & $2 y$ & $\begin{array}{l}2 \text { y (at onset of } \\
\text { walking) }\end{array}$ & $\begin{array}{l}\text { Right hemifacial } \\
\text { flushing and } \\
\text { hyperhidrosis }\end{array}$ & $\begin{array}{l}\text { Exertion } \\
\text { Hot weather }\end{array}$ & $\begin{array}{l}\text { Yes } \\
\text { (contralateral } \\
\text { side) }\end{array}$ & No \\
\hline & $10 y$ & $\begin{array}{l}18 \text { mo (at onset of } \\
\text { walking) }\end{array}$ & $\begin{array}{l}\text { Left hemifacial } \\
\text { flushing and } \\
\text { hyperhidrosis }\end{array}$ & $\begin{array}{l}\text { Exercise } \\
\text { Heat } \\
\text { Sun exposure }\end{array}$ & $\begin{array}{l}\text { Yes } \\
\text { (contralateral } \\
\text { side) }\end{array}$ & No \\
\hline $\begin{array}{l}\text { Yu Phuan and } \\
\text { Tey }^{16}\end{array}$ & $13 y$ & $8 y$ & $\begin{array}{l}\text { Left hemifacial, } \\
\text { hemithorax, } \\
\text { anihidrosis, and } \\
\text { absence of } \\
\text { flushing }\end{array}$ & Exercise & No & No \\
\hline
\end{tabular}

Abbreviation: NA = information unavailable or not specified.

those without Horner syndrome (average onset 6 years, range 14 months-11 years). Symptoms presented when patients started walking or had a provoking factor such as distress, hot weather, or exercise. Out of those patients without Horner syndrome, 2 patients had other significant associated neurologic findings. One 9-year-old patient had harlequin syndrome associated with bilateral tonic pupils with ocular parasympathetic denervation supersensitivity, along the spectrum of Holmes-Adie and Ross syndrome. This patient also had involvement of her neck, upper chest, and arm on the same side as her face. One other patient had associated epilepsy, as well as mental and psychomotor retardation. Except for one patient who presented with absence of flushing and anhidrosis (likely on the affected side), all other patients had isolated unilateral flushing with hyperhidrosis.

Harlequin syndrome can be acquired or congenital. ${ }^{2}$ Acquired causes include trauma (secondary to surgeries or procedures near the cervical or thoracic sympathetic chain), malignancy (such as a compressive tumor), or syrinx. ${ }^{2}$ It has also been proposed but not proven that occlusion of the anterior radicular artery at the third thoracic segment from strenuous exertion, microvascular ischemia, or autoimmune or infectious insult could cause harlequin syndrome. ${ }^{1}$ Other diagnoses should be ruled out including autonomic seizures and autonomic cephalgia. ${ }^{7,8}$ Of note, our patient's episodes were too long to be considered 
autonomic headache. Congenital harlequin syndrome is a diagnosis of exclusion.

The exact pathophysiology of congenital harlequin syndrome is unclear, but it seems to result from autonomic dysfunction of the sympathetic nervous system via a 3-neuron pathway that mediates thermoregulatory flushing and emotional blushing. ${ }^{2}$ The syndrome corresponds to a compensatory overstimulation of the contralateral normal sympathetic chain in response to a dysfunction of the ipsilateral sympathetic chain to maintain thermal regulation of the face. ${ }^{2}$ The sympathetic nerve pathway that innervates the face originates in the hypothalamus (first-order neuron) and synapses in the lateral horn of the spinal cord with preganglionic (second-order) neurons. ${ }^{2}$ The preganglionic neurons exit at $\mathrm{T} 2$ and $\mathrm{T} 3$, ascend along the paravertebral sympathetic chain, and synapse in the superior cervical ganglion with the postganglionic (third-order) neurons, which divide into rostral and caudal fibers. ${ }^{2}$ Rostral fibers travel along the internal carotid artery and innervate the eye and forehead, and caudal fibers travel along the external carotid artery and innervate the lower half of the face. ${ }^{2}$ Autonomic symptoms can occur when involving the parasympathetic neurons in the ciliary ganglion. ${ }^{9}$ Of note, although this was not the case in our patient, a lesion that concomitantly involves a preganglionic neuron at $\mathrm{T} 1$, which involves the sympathetic pupillomotor fibers, would explain a concurrent Horner syndrome on the contralateral side. ${ }^{2}$ Moreover, a more distal lesion from T4 could affect the arm. ${ }^{5}$

To our knowledge, there are no published cases of harlequin syndrome of the face that is bilateral. There are 2 cases of contralateral anhidrosis of the arm from the affected side of the face thought due to multifocal lesions, but both were adults. ${ }^{9,10}$ The etiology of our patient's alternating and occasional bilateral symptoms is unclear. A unilateral defect of the sympathetic ganglion would result in recurrent flushing to the contralateral side due to the compensatory response of the unaffected side, as has been reported. Extrapolating this proposed mechanism, our hypothesis for this patient is that there exists a symmetric insult to the bilateral caudal fibers of postganglionic neurons from $\mathrm{T} 2$ to $\mathrm{T} 3$ that specifically innervate the lower half of the face. Thus, the compensatory response would be the upper half of the face. The occurrence of laterality is attributed to an occasional asymmetric compensatory response during the episode. The insult is unclear, thus the etiology at this point is idiopathic.

The clinical course is also uncertain when there is no underlying lesion and there are sparse data on long-term follow-up in known cases. ${ }^{2}$ In a few but not all cases with long-term follow-up, patients sometimes experienced spontaneous and progressive improvement of symptoms with decrease in frequency and intensity of the episodes as well as requiring a stronger provoking stimulus over the course of several years. ${ }^{2}$ This was thought to be due to progressive weakening of the response of the contralateral sympathetic chain over time. ${ }^{2}$ This seems to be the case in our patient. Patients developed normally and overall, this diagnosis was considered benign. ${ }^{2}$

While harlequin color change has been more widely reported, cases of congenital harlequin syndrome are rarer. It is a dysautonomia of facial flushing and hyperhidrosis with autonomic symptoms that occur when a patient is provoked, thought due to a compensatory sympathetic and parasympathetic response to a defect of the sympathetic chain elsewhere. To our knowledge, our patient is the first presentation of sometimes bilateral symptoms. The etiology of congenital harlequin syndrome is unclear. Based on limited case reports, the clinical course should be benign and anticipated to improve over time.

\section{Author contributions}

Jennifer H. Kang: drafting of manuscript. Muhammad Shahzad Zafar: critical revision of manuscript for intellectual content. Klause Werner: critical revision of manuscript for intellectual content.

\section{Study funding}

No targeted funding reported.

\section{Disclosure}

The authors report no disclosures relevant to the manuscript. Go to Neurology.org/N for full disclosures.

\section{References}

1. Lance JW, Drummond PD, Gandevia SC, Morris JG. Harlequin syndrome: the sudden onset of unilateral flushing and sweating. J Neurol Neurosurg Psychiatry 1988;51:635-642.

2. Miquel J, Piyaraly S, Dupuy A, Cochat P, Phan A. Congenital cases of concomitant harlequin and Horner syndromes. J Pediatr 2017;182:389-392.

3. Neligan GA, Strang LB. A "harlequin" colour change in the newborn. Lancet 1952;2: 1005-1007.

4. Kalapesi FB, Krishnan AV, Kiernan MC. Segmental facial anhidrosis and tonic pupils with preserved deep tendon reflexes: a novel autonomic neuropathy. J Neuroophthalmol 2005;25:5-8.

5. Jain P, Arya R, Jaryal A, Gulati S. Idiopathic harlequin syndrome: a pediatric case. J Child Neurol 2013;28:527-530.

6. Shin RK, Galetta SL, Ting TY, Armstrong K, Bird SJ. Ross syndrome plus: beyond Horner, Holmes-Adie, and harlequin. Neurology 2000;55:1841-1846.

7. Headache Classification Committee of the International Headache Society. The International Classification of Headache Disorders, 3rd edition. Cephalalgia 2018; 38:1-211.

8. Zelnik N, Nir A, Amit S, Iancu TC. Autonomic seizures in an infant: unusual cutaneous and cardiac manifestations. Dev Med Child Neurol 1990;32:74-78.

9. Moon SY, Shin DI, Park SH, Kim JS. Harlequin syndrome with crossed sympathetic deficit of the face and arm. J Korean Med Sci 2005;20:329-330.

10. Corbett M, Abernethy DA. Harlequin syndrome. J Neurol Neurosurg Psychiatry 1999;66:544.

11. Saito H. Congenital Horner's syndrome with unilateral facial flushing. J Neurol Neurosurg Psychiatry 1990;53:85-86.

12. Kaur S, Aggarwal P, Jindal N, et al. Harlequin syndrome: a mask of rare dysautonomic syndromes. Dermatol Online J 2015;21.

13. Kim JY, Lee MS, Kim SY, et al. A pediatric case of idiopathic harlequin syndrome. Korean J Pediatr 2016;59:S125-S128.

14. Vidal Esteban A, Natera-de Benito D, Martinez Sanchez D, et al. Congenital harlequin syndrome as an isolated phenomenon: a case report and review of the literature. Eur J Paediatr Neurol 2016;20:426-430.

15. Lucas P, Legendre L, Pauwels C, Mazereeuw-Hautier J. Harlequin phenomenon associated with neurological abnormalities: a case report. Ann Dermatol Venereol 2016;143:369-371.

16. Yu Phuan CZ, Tey HL. Unilateral facial and upper truncal anhidrosis and absence of physiological flushing: a case of idiopathic harlequin syndrome. Indian J Dermatol Venereol Leprol 2017;83:740. 


\section{Neurology}

\section{Child Neurology: An infant with episodic facial flushing: A rare case and review of congenital harlequin syndrome}

Jennifer H. Kang, Muhammad Shahzad Zafar and Klaus-Georg E. Werner

Neurology 2018;91;278-281

DOI 10.1212/WNL.0000000000005949

This information is current as of August 6, 2018

$\begin{array}{ll}\begin{array}{l}\text { Updated Information } \& \\ \text { Services }\end{array} & \begin{array}{l}\text { including high resolution figures, can be found at: } \\ \text { http://n.neurology.org/content/91/6/278.full }\end{array} \\ \text { References } & \text { This article cites } 15 \text { articles, } 4 \text { of which you can access for free at: } \\ & \text { http://n.neurology.org/content/91/6/278.full\#ref-list-1 } \\ \text { Subspecialty Collections } & \text { This article, along with others on similar topics, appears in the } \\ & \text { following collection(s): } \\ & \text { All Pediatric } \\ \text { http://n.neurology.org/cgi/collection/all_pediatric } \\ \text { Autonomic diseases } \\ \text { http://n.neurology.org/cgi/collection/autonomic_diseases } \\ \text { Clinical neurology examination } \\ \text { http://n.neurology.org/cgi/collection/clinical_neurology_examination } \\ \\ \text { Information about reproducing this article in parts (figures,tables) or in } \\ \text { its entirety can be found online at: } \\ \text { http://www.neurology.org/about/about_the_journal\#permissions } \\ \text { Permissions \& Licensing } \\ \text { Information about ordering reprints can be found online: } \\ \text { http://n.neurology.org/subscribers/advertise }\end{array}$

Neurology ${ }^{\circledR}$ is the official journal of the American Academy of Neurology. Published continuously since 1951, it is now a weekly with 48 issues per year. Copyright (O 2018 American Academy of Neurology. All rights reserved. Print ISSN: 0028-3878. Online ISSN: 1526-632X.

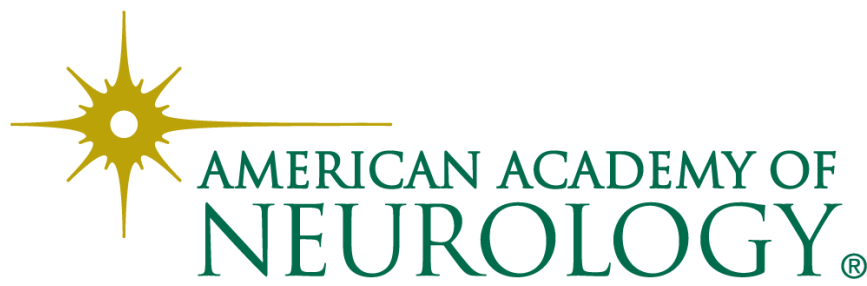

